\title{
An Efficient Oxidation of Benzoins to Benzils by Manganese(II) Schiff Base Complexes Using Green Oxidant
}

\author{
Javad Safari, Zohre Zarnegar, and Fatemeh Rahimi \\ Laboratory of Organic Compound Research, Department of Organic Chemistry, College of Chemistry, University of Kashan, \\ Kashan 87317-51167, Iran \\ Correspondence should be addressed to Javad Safari; safari@kashanu.ac.ir
}

Received 26 June 2012; Accepted 8 August 2012

Academic Editor: Stojan Stavber

Copyright (C) 2013 Javad Safari et al. This is an open access article distributed under the Creative Commons Attribution License, which permits unrestricted use, distribution, and reproduction in any medium, provided the original work is properly cited.

A simple, highly efficient and mild catalytic oxidation of benzoins to the corresponding benzils was developed using manganese(II) Schiff base complexes as novel and reusable catalyst in the presence of acetonitrile as solvent and $\mathrm{H}_{2} \mathrm{O}_{2}$ as green oxidant. This simple method affords benzil derivatives at room temperature in short reaction times with high yield and purity. This convenient procedure will allow a further increase of the diversity within the benzil family.

\section{Introduction}

Benzil, an alpha diketone, is one of the important organic intermediates and has received an enormous attention because of its practical applications in organic and pharmaceutical industry such as photosensitive and synthetic reagents [1-3]. The oxidation of benzoins is one of the most efficient and practical methods for the synthesis of benzils. In general, the oxidation of benzoins to benzils has been accomplished by classical reagents such as nitric acid [4], Fehling's solution [4], thallium nitrate [5], ammonium nitrate-copper acetate [6], bismuth nitrate-copper acetate [7], and ferric nitrate [8]. In addition, the oxidation of benzoins to benzils was studied using $\mathrm{p}$-benzoquinone or air in the presence of $\left(\mathrm{Fe}^{\mathrm{II}}(\mathrm{SPh})_{4}\right)_{2}$ and $\left(\mathrm{Fe}^{\mathrm{II}}(\mathrm{SePh})_{4}\right)_{2}$ [9], $\mathrm{Fe}(\mathrm{II})$-cysteine peptide complexes [7] and ter. butyl peroxide [10]. The electrochemical oxidation of benzoins to benzils in the presence of a catalytic amount of KI in basic media [11] was also studied. Also, Paris et al. used ( $\mathrm{Mn}^{\mathrm{III}}$ (pydx-en) $\mathrm{Cl}\left(\mathrm{H}_{2} \mathrm{O}\right)$ )- $\mathrm{Y}$ as catalyst and $\mathrm{H}_{2} \mathrm{O}_{2}$ as an oxidant for oxidation of benzoin to benzil in methanol at reflux temperature [12].

However, in spite of their potential utility, some of the reported methods suffer from drawbacks such as longer reaction time, lower yields, expensive catalysts, harsh conditions, or complexity of workup. There still appears a need either to improve the existing oxidation methods or to introduce novel reagents to permit better selectivity under milder conditions and with easy work-up procedures [12].

Transition metal catalysts supported by Schiff base ligands have assumed a prominent role in modern synthesis. Schiff base complexes of transition metals having $\mathrm{O}$ and $\mathrm{N}$ donor atoms have shown an exponential increase as inorganic catalysts for various organic transformations. Distinct advantages of such ligands include their low cost, facile syntheses, and convenient incorporation of inexpensive, chiral 1,2-diamines into the ligand backbone. Moreover, the ligands generally afford air and moisture-stable complexes. On the other hand, coordination chemistry of manganese has been studied extensively so that that manganese center is surrounded by $\mathrm{O}$ - or $\mathrm{N}$-donor ligands $[13,14]$. In addition, they also act as catalysts for important reactions [15-20].

The development of manganese(II) Schiff base heterogeneous catalysts for oxidation reaction has become a major area of research recently [21-23], as the potential advantages of these materials over homogeneous systems can make a major impact on the environmental performance of a synthesis. While the homogeneous catalysts exhibit excellent activity and selectivity, the technical problems encountered 
in their use, such as the difficulty in product separation, long reaction times, self-aggregation of active sites, and undesirable side products [24]. In order to overcome the problems associated with homogeneous systems, heterogeneous catalyst was used in Organic Chemistry. In the present study, we have reported a simple and convenient method for the effective oxidation of benzoin derivatives to corresponding benzils under mild conditions by manganese(II) Schiff base complex and $\mathrm{H}_{2} \mathrm{O}_{2}$ at room temperature (Scheme 1). $\mathrm{H}_{2} \mathrm{O}_{2}$ is inexpensive and environmental friendly oxidant. It is observed that the homogeneous catalyst is very active in high conversion rate of benzoin to benzil. However, the homogeneous catalysts have the difficulty in separating the catalysts from the reaction mixture at the end of the process. But, this simple method aimed to overcome the limitations. The easy removal of the catalyst makes them better compared to other homogeneous catalyst. Moreover, the catalytic oxidation can be carried out at room temperature in short reaction time with high yield and purity.

\section{Experimental}

2.1. Materials. Chemicals were purchased from the Merck and Fluka Chemical Companies in high purity. All of the materials were of commercial reagent grade. The amines and carbonyl compounds were purified by standard procedures [25].

2.2. Apparatus. IR spectra were recorded as $\mathrm{KBr}$ pellets on a Perkin-Elmer 781 spectrophotometer and on an Impact 400 Nicolet FTIR spectrophotometer. ${ }^{1} \mathrm{H}$ NMR $(400 \mathrm{MHz})$ and ${ }^{13} \mathrm{C}$ NMR $(100 \mathrm{MHz})$ spectra were recorded on a Bruker DPX-400 Avance spectrometer. Tetramethyl silane (TMS) was used as an internal reference. UV spectra were recorded on a Hitachi 200-20 spectrometer using spectrophotometric grade ethanol (Baker). The melting points were determined by a Yanagimoto micromelting point apparatus. The purity determination of the substrates and reaction monitoring were accomplished by thin layer chromatography (TLC) on silica gel polygram SILG/UV 254 plates.

\subsection{General Procedure}

2.3.1. General Procedure for the Preparation of the Schiff Base Ligands. To a mixture of salicylaldehyde $(0.4 \mathrm{~g}, 3.27 \mathrm{mmol})$ in $\mathrm{MeOH}$ was added the diamine $(1.65 \mathrm{mmol})$ with stirring in one portion. The stirring was continued to complete the reaction. The progress of the reaction was monitored by thin layer chromatography (TLC). After the completion of the reaction, a colored substance was obtained. The solid product was filtered off and washed with cold $\mathrm{MeOH}$. The crude product was purified by recrystallization from ethanol and the pure Schiff base was obtained in high yield after leaving for the appropriate time. The Schiff base products were identified by physical and spectroscopic data and by a comparison with authentic samples prepared in accordance to the literature procedures (Scheme 2) [26].
$N, N^{\prime}$-Bis(salicylidene)ethylenediamin (Salen): Yellow. Yield: $93 \%$; M.P: $125-127^{\circ}$ C. ${ }^{1} \mathrm{H}$ NMR $\left(\mathrm{CDCl}_{3}, 400 \mathrm{MHz}\right)$ $\delta: 3.96(\mathrm{~s}, 4 \mathrm{H}), 6.88(\mathrm{t}, 2 \mathrm{H}, \mathrm{Ar}), 6.95(\mathrm{t}, 2 \mathrm{H}, \mathrm{Ar}), 7.20(\mathrm{q}$, $2 \mathrm{H}, \mathrm{Ar}), 7.28$ (q, 2H, Ar), 8.23 (s, 2CH), 13.23 (s, 2OH) ppm; ${ }^{13} \mathrm{C} \mathrm{NMR}\left(\mathrm{CDCl}_{3}, 100 \mathrm{MHz}\right) \delta: 57.41,117.32,118.91$, $121.62,130.39,132.31,158.33,161.19$; IR $\left(\mathrm{KBr}, v_{\max }, \mathrm{cm}^{-1}\right)$ : 3250-3550, 1634, 1416, 1570, 1285.

2.3.2. General Procedure for the Preparation of the Schiff Base Complexes of $\mathrm{Mn}(\mathrm{II})$. To a solution of the Schiff base ligand $(1 \mathrm{mmol})$ in $\mathrm{MeOH}(10 \mathrm{~mL})$ was added $\mathrm{Mn}\left(\mathrm{O}_{2} \mathrm{CCH}_{3}\right)_{2}$ $(1 \mathrm{mmol})$ dropwise under refluxing conditions. The reaction mixture was stirred to complete the reaction. The progress of the reaction was monitored by TLC. After the completion of complex formation, a colored substance was obtained. The solid product was filtered off and washed with $\mathrm{MeOH}$. The crude product was purified by recrystallization from methanol and the pure Schiff base complex was obtained. The complex products were identified by comparison with authentic samples prepared in accordance to the literature procedures (Scheme 2) [26].

$N, N^{\prime}$-Bis(salicylidene)ethylenediaminemanganese(II) (Mn (Salen)): Dark green. Yield: $88 \%$; M.P.: $>300^{\circ}$ C. ${ }^{1} \mathrm{H}$ NMR $\left(\mathrm{CDCl}_{3}, 400 \mathrm{MHz}\right) \delta: 4.3$ (s (br), 4H), 6.35 (t, 2H, Ar), 7.24 (t, 2H, Ar), 7.41 (q, 2H, Ar), 7.39 (q, 2H, Ar), 8.71 (s (br), $2 \mathrm{CH}), \mathrm{ppm} ;{ }^{13} \mathrm{C} \mathrm{NMR}\left(\mathrm{CDCl}_{3}, 100 \mathrm{MHz}\right) \delta: 57.41,117.32$, $118.91,121.62,130.39,132.31,158.33,161.19$; IR (KBr, $v_{\max }$, $\left.\mathrm{cm}^{-1}\right): 1621,1402,1568,1283$.

\subsubsection{General Procedure for Oxidation of Benzoin to Benzil.} Oxidation of benzoin was carried out using Mn(II) Schiff base complexes as a catalyst in a $50 \mathrm{~mL}$ flask. In a typical reaction, $1 \mathrm{mmol}$ of benzoin was dissolved in $10 \mathrm{~mL}$ acetonitrile in the presence of $\mathrm{KOH}$. Oxidation of reaction mixture was done with $\mathrm{H}_{2} \mathrm{O}_{2}$ with catalytic amount manganese(II) Schiff base. The reaction mixture was stirred to completion at room temperature and gave excellent yields under the mild oxidation conditions. The completion of reaction was monitored by TLC (petroleum ether: ethyl acetate, $4: 1 \mathrm{v} / \mathrm{v}$ ). After the completion of the reaction, the catalyst was removed by addition of absolute methanol to the mixture and Schiff base complex was recrystallized from petroleum ether. The solvent was evaporated, and the pure benzil derivatives were obtained. The structure of these compounds has been investigated using different methods of spectroscopy and spectrometry: UV, ${ }^{1} \mathrm{H}$ NMR, ${ }^{13} \mathrm{C}$ NMR, IR, and MS.

\section{Results and Discussion}

Schiff base complexes of metal(II) have been recognized as being among the most promising catalysts for various reactions. We used $\mathrm{Mn}$ (II) Schiff base complexes as catalyst and $\mathrm{H}_{2} \mathrm{O}_{2}$ as oxidant, for the oxidation of some benzoins into benzils at room temperature in high yield.

Firstly, among the various oxidants, it was concluded that the best activity and selectivity can be achieved by $\mathrm{H}_{2} \mathrm{O}_{2}$ under optimized reaction conditions. Diluted solution 
<smiles>[R]c1ccc(C(=O)C(=O)c2ccc(C(=O)c3ccc([R])cc3)cc2)cc1</smiles>

Scheme 1: Oxidation of symmetrical and unsymmetrical benzoin derivatives to benzil derivatives using $\mathrm{H}_{2} \mathrm{O}_{2}$ and manganese(II) Schiff base complex.

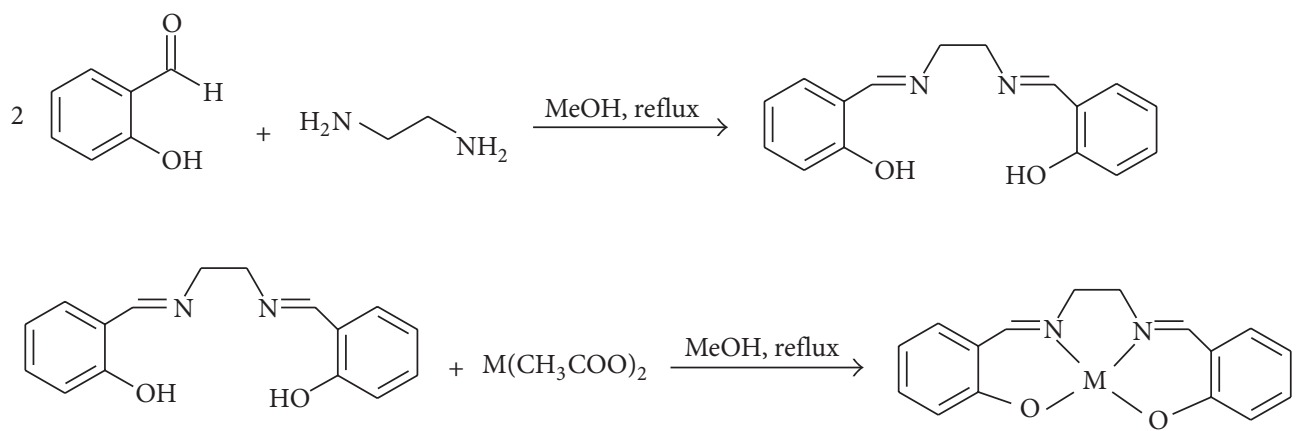

Scheme 2: Preparation of the Schiff base complexes of metal(II) as catalyst.

of hydrogen peroxide is a universal, ecologically clean and convenient way to handle reagents for different oxidations in the liquid phase $[27,28]$. This is an environmentally friendly oxidizing agent as its breakdown products are water and oxygen. Therefore, its decomposition produces no other pollutant in the environment. As shown in Table 1, the effect of Oxidant on the reaction was studied by considering substrate-to-oxidant ratios of $1: 1,1: 1.5,1: 2,1: 2.5$, and $1: 3$ for the substrate $(0.2 \mathrm{~g}, 1 \mathrm{mmol})$ in $10 \mathrm{~mL}$ of $\mathrm{CH}_{3} \mathrm{CN}$ at room temperature. The yield increases from $52 \%$ to $98 \%$ with increasing substrate-to-oxidant ratios from $1: 1$ to $1: 2$. At the substrate to oxidant ratio of $1: 2$, the best yield of benzil was achieved (Table 1, Entry 3). Experiments under the same conditions in the absence of catalyst were also performed and only small amounts of product were detected in the reaction mixture.

We initiated a solvent screen to explore the effect of different solvents on the oxidation of benzoin and also summarized in Table 2. The results in Table 2 show that the highest yield of benzil was achieved with acetonitrile. When other solvents were used, no significant improvement in the yield was observed. In the oxidation procedure, acetonitrile was chosen because of its high polarity and solubility of catalyst in the solvent.

After the completion of the reaction, the catalyst was removed by addition of absolute methanol to the mixture and Schiff base complex was recrystallized from petroleum ether. Then the solvent was removed by evaporation under reduced pressure to give the pure products. Under this condition, several benzoin derivatives were oxidized to the corresponding benzils. The results are summarized in Table 3. Oxidation of the benzoin substrates proceeded with decomposition of hydrogen peroxide in the presence of the Schiff base complex catalyst at room temperature. The results clearly suggest that $\mathrm{Mn}$ (II) Schiff base complex efficiently catalyses the conversion of benzoin to benzil in $\mathrm{CH}_{3} \mathrm{CN}$. The greater activity of the $(\mathrm{OH})_{2}$-salen system has clearly arisen from the existence of an electron donating ligand which facilitates the electron transfer rate, a process that has previously been observed in other oxidation reactions [29-34]. A cyclic mechanism has been proposed for the oxidation of benzoin using catalyst Mn(II) Schiff base complex with hydrogen peroxide as an oxidant (Scheme 3). An oxygen molecule from decomposition of $\mathrm{H}_{2} \mathrm{O}_{2}$ reacts with $\mathrm{Mn}$ (II) to form an oxomanganese complex A $[35,36]$, which undergoes oxidative addition to benzoin and gives an intermediate B which finally undergoes reductive elimination to give the desired product [37] and $\mathrm{Mn}$ (II) is regenerated back.

As shown in Table 3, the oxidation of benzoins by $\mathrm{Mn}$ (II) Schiff base complex was carried out in good yield at room temperature. From the results in Table 3, it seems that the benzoins containing electron-donating group were found to be more reactive and could be oxidized more easily (b and f). In contrast, the benzoins containing electron-withdrawing group have shown lower reactivity $(j)$. This shows that the electronic effects of substituents have a significant role in the oxidation. 
TABLE 1: The effect of reaction conditions on the oxidation of benzoin in the presence of $\mathrm{Mn}$ (II) Schiff base complex in $\mathrm{CH}_{3} \mathrm{CN}_{\text {at }}$ room temperature.

\begin{tabular}{lcccc}
\hline Entry & Molar ratio & Time & Schiff base complexe (mmol) & Isolated yield (\%) \\
\hline 1 & $1: 1$ & 25 & 0.01 & 52 \\
2 & $1: 1.5$ & 25 & 0.01 & 68 \\
3 & $1: 2$ & 25 & 0.01 & 98 \\
4 & $1: 2.5$ & 25 & 0.01 & 82 \\
5 & $1: 3$ & 25 & 0.01 & 75 \\
\hline
\end{tabular}

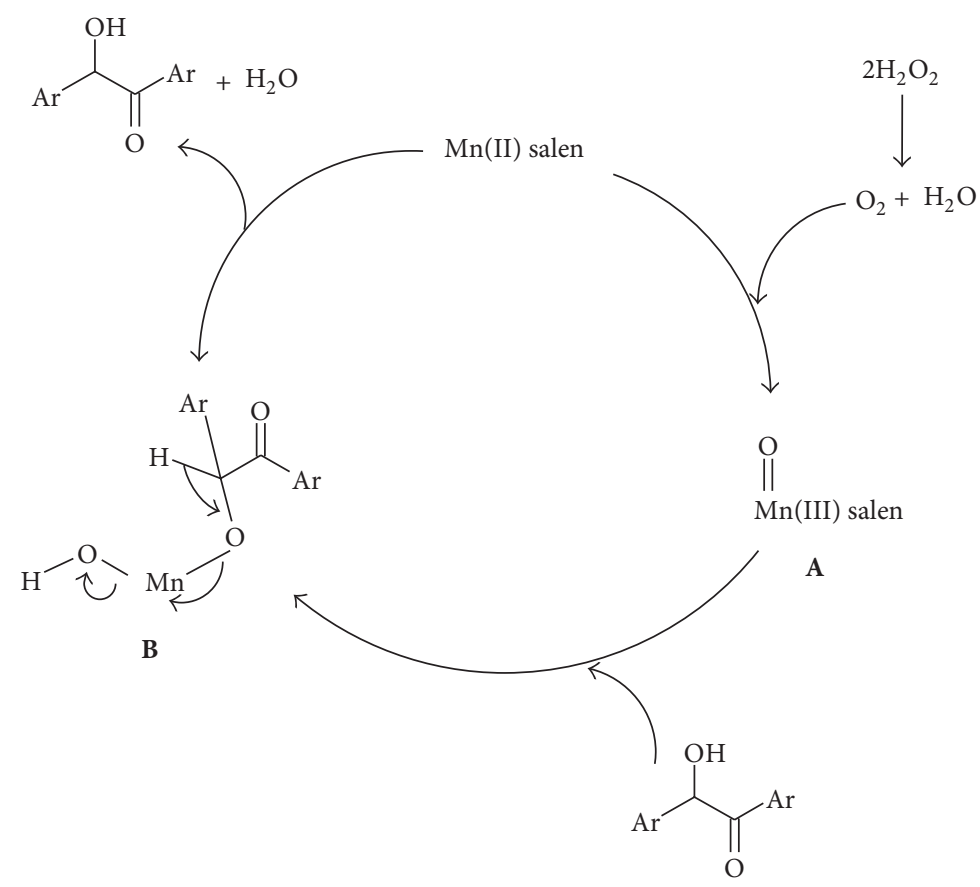

Scheme 3: Proposed catalytic cycle for the oxidation of benzoins to benzils using catalyst Mn(II) Schiff base complex with hydrogen peroxide as an oxidant.

TABLE 2: The effect of solvent on the yield of reaction at room temperature.

\begin{tabular}{lcc}
\hline Solvent & Unreacted benzoin (\%) & Yield $(\%)^{\mathrm{a}}$ \\
\hline $\mathrm{CH}_{3} \mathrm{CN}$ & 2 & 98 \\
$\mathrm{CCl}_{4}$ & 40 & 60 \\
$\mathrm{CH}_{2} \mathrm{Cl}_{2}$ & 70 & 30 \\
$\mathrm{CH}_{3} \mathrm{OH}$ & - & - \\
$\mathrm{CH}_{3} \mathrm{CH}_{2} \mathrm{OH}$ & - & - \\
\hline
\end{tabular}

aields refer to the pure isolated product.

After completion of reaction, the catalyst was washed with petroleum ether ( 3 times) and then kept for drying at $100^{\circ} \mathrm{C}$ for $2 \mathrm{~h}$, after which the catalyst was reused for next cycle without any appreciable loss of its activity. Similarly, reusability for sequential reaction was also carried out and catalyst was found to be reusable for five cycles (Table 4).
Finally, the structure of these compounds has been investigated using different methods of spectroscopy and spectrometry: UV, ${ }^{1} \mathrm{H}$ NMR, ${ }^{13} \mathrm{C}$ NMR, IR, and MS.

\section{Spectroscopic Data}

Compound (a) Benzil: UV $\left(\mathrm{CH}_{3} \mathrm{OH}\right) \lambda_{\max }: 224 \mathrm{~nm} ;{ }^{1} \mathrm{H}$ NMR $\left(\mathrm{CDCl}_{3}, 400 \mathrm{MHz}\right) \delta: 7.54(\mathrm{t}, 2 \mathrm{H}, \mathrm{CH}, J=7.6 \mathrm{~Hz}), 7.69(\mathrm{t}$, $4 \mathrm{H}, \mathrm{CH}, J=7.6 \mathrm{~Hz}), 7.98(\mathrm{~d}, 4 \mathrm{H}, \mathrm{CH}, J=7.6 \mathrm{~Hz}) \mathrm{ppm} ;{ }^{13} \mathrm{C}$ $\mathrm{NMR}\left(\mathrm{CDCl}_{3}, 100 \mathrm{MHz}\right) \delta: 128.90(4 \mathrm{CH}), 129.70(4 \mathrm{CH}), 133$ (2CH), 134.93 (2C), 194.30 (2CO) ppm; IR (KBr, $\left.v_{\max }, \mathrm{cm}^{-1}\right)$ : $1650(\mathrm{C}=\mathrm{O}, \mathrm{s}), 1450,1580(\mathrm{C}=\mathrm{C}, \mathrm{m}), 720(\mathrm{CH}, \mathrm{m})$; MS (70 Ev, EI) $m / z=208\left(\mathrm{M}^{+\cdot}\right), 104,76$.

Compound (b), 4,4'-dimethoxybenzil: UV $\left(\mathrm{CH}_{3} \mathrm{OH}\right)$ $\lambda_{\text {max }}: 225 \mathrm{~nm} ;{ }^{1} \mathrm{H} \mathrm{NMR}\left(\mathrm{CDCl}_{3}, 400 \mathrm{MHz}\right) \delta: 3.89(\mathrm{~s}, 6 \mathrm{H}$, $\left.\mathrm{OCH}_{3}\right), 6.97(\mathrm{~d}, 4 \mathrm{H}, \mathrm{CH}, J=8.8 \mathrm{~Hz}), 7.95(\mathrm{~d}, 4 \mathrm{H}, \mathrm{CH}, J=$ $8.8 \mathrm{~Hz}) \mathrm{ppm} ;{ }^{13} \mathrm{C} \mathrm{NMR}\left(\mathrm{CDCl}_{3}, 100 \mathrm{MHz}\right) \delta: 55.62\left(2 \mathrm{OCH}_{3}\right)$, 114.29 (4CH), 126.19 (4CH), 132.30 (2C), 64.86 (2C), 193.54 
TABLE 3: Oxidation of benzoin derivatives using $\mathrm{H}_{2} \mathrm{O}_{2}$ in the presence of $\mathrm{Mn}$ (II) Schiff base complex in $\mathrm{CH}_{3} \mathrm{CN}$ at room temperature.

\begin{tabular}{|c|c|c|c|c|c|}
\hline & $\mathrm{R}^{1}$ & $\mathrm{R}^{2}$ & Time (min) & Yield $^{\mathrm{a}}(\%)$ & $m p_{\text {rep }} / \mathrm{mp}_{\text {lit. }}\left({ }^{\circ} \mathrm{C}\right)$ \\
\hline $\mathrm{a}$ & $\mathrm{H}$ & $\mathrm{H}$ & 25 & 98 & $92-95 / 94-96$ [24] \\
\hline $\mathrm{b}$ & $4-\mathrm{OCH}_{3}$ & $4-\mathrm{OCH}_{3}$ & 20 & 91 & $133-135 / 132-134[24]$ \\
\hline c & $4-\mathrm{NCH}_{3}$ & $\mathrm{H}$ & 30 & 70 & $117-118 / 115-116[24]$ \\
\hline d & $4-\mathrm{CH}_{3}$ & $4-\mathrm{CH}_{3}$ & 23 & 78 & $103-105 / 101-104$ [24] \\
\hline e & $4-\mathrm{OCH}_{3}$ & $\mathrm{H}$ & 20 & 85 & $65-67 / 62-63[24]$ \\
\hline $\mathrm{f}$ & $\mathrm{NC}_{5} \mathrm{H}_{5}$ & $\mathrm{NC}_{5} \mathrm{H}_{5}$ & 22 & 89 & $119-121$ \\
\hline g & 2,4- $\mathrm{diOCH}_{3}$ & 2,4- $\mathrm{diOCH}_{3}$ & 35 & 73 & $195-197$ \\
\hline h & $\mathrm{H}$ & $3-\mathrm{OCH}_{3}$ & 21 & 58 & $133-134 / 133$ [24] \\
\hline i & $\mathrm{H}$ & $4-\mathrm{CH}_{3}$ & 26 & 84 & $27-28 / 31[24]$ \\
\hline j & $4-\mathrm{CH}_{3}$ & $3-\mathrm{Br}$ & 30 & 45 & $141-142$ \\
\hline
\end{tabular}

Isolated yields.

TABLE 4: Reusability study of Mn(II) Schiff base complex as catalyst for oxidation of benzoin.

\begin{tabular}{lc}
\hline Run & Yield (\%) \\
\hline 1 & 98 \\
2 & 95 \\
3 & 90 \\
4 & 88 \\
5 & 85 \\
\hline
\end{tabular}

(2CO) ppm; IR $\left(\mathrm{KBr}, v_{\max }, \mathrm{cm}^{-1}\right): 1650(\mathrm{C}=\mathrm{O}, \mathrm{s}), 1586(\mathrm{C}=\mathrm{C}$, m), $769(\mathrm{CH}, \mathrm{m})$; MS (70 Ev, EI) $m / z=270\left(\mathrm{M}^{+}\right), 135,120$, 107, 104, 76.

Compound (c) 4-Dimethylaminobenzil: UV $\left(\mathrm{CH}_{3} \mathrm{OH}\right)$ $\lambda_{\max }: 229 \mathrm{~nm} ;{ }^{1} \mathrm{H} \mathrm{NMR}\left(\mathrm{CDCl}_{3}, 400 \mathrm{MHz}\right) \delta: 3.38(\mathrm{~s}, 6 \mathrm{H}$, $\left.\mathrm{CH}_{3}\right), 6.67(\mathrm{~d}, 2 \mathrm{H}, \mathrm{CH}, J=5.2 \mathrm{~Hz}), 7.48(\mathrm{~d}, 2 \mathrm{H}, \mathrm{CH}$, $J=8.1 \mathrm{~Hz}), 7.61(\mathrm{~d}, 2 \mathrm{H}, \mathrm{CH}, J=8.1 \mathrm{~Hz}), 7.8(\mathrm{~d}, \mathrm{H}, \mathrm{CH}$, $J=8.1 \mathrm{~Hz}), 8.28(\mathrm{~d}, 2 \mathrm{H}, \mathrm{CH}, J=5.2 \mathrm{~Hz}) \mathrm{ppm} ;{ }^{13} \mathrm{C} \mathrm{NMR}$ $\left(\mathrm{CDCl}_{3}, 100 \mathrm{MHz}\right) \delta: 55.91\left(2 \mathrm{CH}_{3}\right), 111.20(2 \mathrm{CH}), 128.90$ (2CH), $129.01(\mathrm{C}), 129.70(2 \mathrm{CH}), 135.37(\mathrm{CH}), 135.50(\mathrm{C})$, 141.47 (C), 153.76 (C), 196.72 (CO) ppm; IR (KBr, $v_{\max }$, $\left.\mathrm{cm}^{-1}\right):$ 1650, $1700(\mathrm{C}=\mathrm{O}, \mathrm{s}), 1440,1620(\mathrm{C}=\mathrm{C}, \mathrm{m}), 705(\mathrm{CH}$, m); MS (70 Ev, EI) $252\left(\mathrm{M}^{+*}\right), 148,120,104,76$.

Compound (d), 4,4'-dimethylbenzil: $\mathrm{UV}\left(\mathrm{CH}_{3} \mathrm{OH}\right) \lambda_{\max }$ : $225 \mathrm{~nm} ;{ }^{1} \mathrm{H} \mathrm{NMR}\left(\mathrm{CDCl}_{3}, 400 \mathrm{MHz}\right) \delta: 2.45\left(\mathrm{~s}, 6 \mathrm{H}, \mathrm{CH}_{3}\right), 7.4$ $(\mathrm{d}, 4 \mathrm{H}, \mathrm{CH}, J=7.2 \mathrm{~Hz}), 7.75$ (d, $4 \mathrm{H}, \mathrm{CH}, J=7.6 \mathrm{~Hz}) \mathrm{ppm}$; ${ }^{13} \mathrm{C} \mathrm{NMR}(\mathrm{CDCl} 3,100 \mathrm{MHz}) \delta: 21.95\left(2 \mathrm{CH}_{3}\right), 129.72(4 \mathrm{CH})$, 130.03 (4CH), 130.69 (2C), 146.11 (2C), 194.54 (2CO) ppm; IR $\left(\mathrm{KBr}, v_{\max }, \mathrm{cm}^{-1}\right): 1650,(\mathrm{C}=\mathrm{O}, \mathrm{s}), 1586(\mathrm{C}=\mathrm{C}, \mathrm{m}), 769$ $(\mathrm{CH}, \mathrm{m})$; MS (70 Ev, EI) $238\left(\mathrm{M}^{+\cdot}\right), 119,104,91,76$.

Compound (e), 4-Methoxybenzil: $\mathrm{UV}\left(\mathrm{CH}_{3} \mathrm{OH}\right) \lambda_{\text {max }}$ : $228 \mathrm{~nm} ;{ }^{1} \mathrm{H}$ NMR $\left(\mathrm{CDCl}_{3}, 400 \mathrm{MHz}\right) \delta: 3.76$ (s, 3H, $\left.\mathrm{OCH}_{3}\right)$, $6.82(2 \mathrm{H}, \mathrm{d}), 7.34-7.61(5 \mathrm{H}, \mathrm{m}), 7.86(2 \mathrm{H}, \mathrm{d}) \mathrm{ppm},{ }^{13} \mathrm{C} \mathrm{NMR}$ $\left(\mathrm{CDCl}_{3}, 100 \mathrm{MHz}\right) \delta$ : $55.19\left(\mathrm{CH}_{3}\right), 113.20(2 \mathrm{CH}), 128.90$ $(2 \mathrm{CH}), 129.70(2 \mathrm{CH}), 130.30(\mathrm{C}), 131.37(\mathrm{CH}), 133(2 \mathrm{CH})$, 133.26 (C), 164.69 (C), 194.30 (CO) ppm; IR (KBr, $v_{\max }$, $\left.\mathrm{cm}^{-1}\right)$ : 1650, $(\mathrm{C}=\mathrm{O}, \mathrm{s}), 1586(\mathrm{C}=\mathrm{C}, \mathrm{m}), 769(\mathrm{CH}, \mathrm{m}) ; \mathrm{MS}$ (70 Ev, EI) $239\left(\mathrm{M}^{+\cdot}\right), 135,107,104,76$.

Compound (f), 2-pyridil: UV $\left(\mathrm{CH}_{3} \mathrm{OH}\right) \lambda_{\max }: 365 \mathrm{~nm} ;{ }^{1} \mathrm{H}$ $\operatorname{NMR}\left(\mathrm{CDCl}_{3}, 400 \mathrm{MHz}\right) \delta: 7.49(\mathrm{t}, 2 \mathrm{H}, \mathrm{CH}, J=8.1 \mathrm{~Hz}), 7.91$ $(\mathrm{t}, 2 \mathrm{H}, \mathrm{CH}, J=8.1 \mathrm{~Hz}), 8.18(\mathrm{~d}, 2 \mathrm{H}, \mathrm{CH}, J=8.1 \mathrm{~Hz}), 8.56$ $(\mathrm{d}, 2 \mathrm{H}, \mathrm{CH}, J=8.1 \mathrm{~Hz}) \mathrm{ppm} ;{ }^{13} \mathrm{C} \mathrm{NMR}(\mathrm{CDCl} 3,100 \mathrm{MHz})$ $\delta$ : $122.27(2 \mathrm{CH}), 127.99(2 \mathrm{CH}), 137.26(2 \mathrm{CH}), 149.46(2 \mathrm{CH})$, 151.65 (2C), 197.02 (2CO) ppm; IR (KBr, $\left.v_{\max }, \mathrm{cm}^{-1}\right): 1713$ $(\mathrm{C}=\mathrm{O}, \mathrm{s}), 1274(\mathrm{C}=\mathrm{N}, \mathrm{s}), 1505(\mathrm{C}=\mathrm{C}, \mathrm{m}) ; \mathrm{MS}$ (70 Ev, EI) $m / z=212\left(\mathrm{M}^{+\cdot}\right), 106,78$.

Compound (g), 2,2',4,4'-tetramethoxybenzil: UV $\left(\mathrm{CH}_{3}\right.$ $\mathrm{OH}) \lambda_{\max }: 226 \mathrm{~nm} ;{ }^{1} \mathrm{H} \mathrm{NMR}\left(\mathrm{CDCl}_{3}, 400 \mathrm{MHz}\right) \delta: 3.88(\mathrm{~s}$, $\left.3 \mathrm{H}, \mathrm{OCH}_{3}\right), 3.90\left(\mathrm{~s}, 3 \mathrm{H}, \mathrm{OCH}_{3}\right), 6.44(\mathrm{~s}, 2 \mathrm{H}, \mathrm{CH}), 6.53(\mathrm{~d}, 2 \mathrm{H}$, $\mathrm{CH}, J=8.4 \mathrm{~Hz}), 7.81(\mathrm{~d}, 2 \mathrm{H}, \mathrm{CH}, J=8.8 \mathrm{~Hz}) \mathrm{ppm} ;{ }^{13} \mathrm{C} \mathrm{NMR}$ $\left(\mathrm{CDCl}_{3}, 100 \mathrm{MHz}\right) \delta: 55.23\left(\mathrm{OCH}_{3}\right), 55.80\left(\mathrm{OCH}_{3}\right), 101.58$ $(2 \mathrm{CH}), 113.03(2 \mathrm{CH}), 116.91(2 \mathrm{C}), 131.22(2 \mathrm{CH}), 161.83$ (2C), 162.93 (2C), 186.91 (2CO) ppm; IR (KBr, $\left.v_{\max }, \mathrm{cm}^{-1}\right)$ : 1630-1680 (C=O, s), 1470, 1618 (C=C, m), 738 (CH, m); MS $(70 \mathrm{Ev}, \mathrm{EI}) \mathrm{m} / z=330\left(\mathrm{M}^{+\cdot}\right), 167,135,107,104,76$.

Compound (h), 3-Methoxybenzil: UV $\left(\mathrm{CH}_{3} \mathrm{OH}\right) \lambda_{\max }$ : $234 \mathrm{~nm} ;{ }^{1} \mathrm{H}$ NMR $\left(\mathrm{CDCl}_{3}, 400 \mathrm{MHz}\right) \delta: 3.72\left(\mathrm{~s}, 3 \mathrm{H}, \mathrm{OCH}_{3}\right)$, $7.01(1 \mathrm{H}, \mathrm{t}), 7.1(1 \mathrm{H}, \mathrm{s}) 7.32(1 \mathrm{H}, \mathrm{d}), 751(2 \mathrm{H}, \mathrm{t}), 7.60(1 \mathrm{H}$, t), $7.72(2 \mathrm{H}, \mathrm{d}) \mathrm{ppm} ;{ }^{13} \mathrm{C} \mathrm{NMR}\left(\mathrm{CDCl}_{3}, 100 \mathrm{MHz}\right) \delta: 54.00$ $\left(\mathrm{OCH}_{3}\right), 116.80(\mathrm{CH}), 120.13(\mathrm{CH}), 124.16(\mathrm{CH}), 128.90$ $(2 \mathrm{CH}), 129.70(2 \mathrm{CH}), 131.05(\mathrm{CH}), 131.37(\mathrm{CH}), 132.88(\mathrm{C})$, 135.27 (C), 163.09 (C), 193.41 (CO), 194.30 (CO) ppm; IR $\left(\mathrm{KBr}, v_{\max }, \mathrm{cm}^{-1}\right): 1660,(\mathrm{C}=\mathrm{O}, \mathrm{s}), 1396,1613(\mathrm{C}=\mathrm{C}, \mathrm{m}), 725$ (CH, m); MS (70 Ev, EI) $239\left(\mathrm{M}^{+*}\right), 135,107,104,76$.

Compound (i), 4-Methylbenzil: $\mathrm{UV}\left(\mathrm{CH}_{3} \mathrm{OH}\right) \lambda_{\max }$ : $223 \mathrm{~nm} ;{ }^{1} \mathrm{H}$ NMR $\left(\mathrm{CDCl}_{3}, 400 \mathrm{MHz}\right) \delta: 2.34\left(\mathrm{~s}, 3 \mathrm{H}, \mathrm{CH}_{3}\right)$, $7.3(\mathrm{~m}, 2 \mathrm{H}), 7.35(\mathrm{~m}, 2 \mathrm{H}), 7.42(\mathrm{t}, 1 \mathrm{H}, J=8 \mathrm{~Hz}), 7.55(\mathrm{t}$, $2 \mathrm{H}, J=8,7.2 \mathrm{~Hz}$ ), 7.92 (d.d, $2 \mathrm{H}, J=7.92,1.2 \mathrm{~Hz}) \mathrm{ppm}$; ${ }^{13} \mathrm{C} \mathrm{NMR}\left(\mathrm{CDCl}_{3}, 100 \mathrm{MHz}\right) \delta: 22.06\left(\mathrm{CH}_{3}\right), 122.71(2 \mathrm{CH})$, $130.12(2 \mathrm{CH}), 130.28(2 \mathrm{CH}), 131.18(2 \mathrm{CH}), 132.54(2 \mathrm{CH})$, 133.17 (C), 133.83 (C), 147.02 (C), 193.95 (CO), 194.08 (CO) ppm; IR (KBr, $\left.v_{\max }, \mathrm{cm}^{-1}\right): 1640,1680,(\mathrm{C}=\mathrm{O}, \mathrm{s}), 1420,1630$ $(\mathrm{C}=\mathrm{C}, \mathrm{m}), 724(\mathrm{CH}, \mathrm{m})$; MS (70 Ev, EI) $223\left(\mathrm{M}^{+\cdot}\right), 119,104$, 76.

Compound (j), 3-Bromo-4'-methylbenzil: UV $\left(\mathrm{CH}_{3} \mathrm{OH}\right)$ $\lambda_{\text {max }}: 227 \mathrm{~nm} ;{ }^{1} \mathrm{H} \mathrm{NMR}\left(\mathrm{CDCl}_{3}, 400 \mathrm{MHz}\right) \delta: 2.42(\mathrm{~s}, 3 \mathrm{H}$, $\left.\mathrm{CH}_{3}\right), 7.34(\mathrm{t}, 1 \mathrm{H}, \mathrm{CH}), 7.61(\mathrm{~d}, 1 \mathrm{H}, \mathrm{CH}), 7.74(\mathrm{~d}, 3 \mathrm{H}, 3 \mathrm{CH})$, 8.04 (s, H, CH), 8.59 (s, 1H, CH), 8.65 (s, 1H, CH) ppm; ${ }^{13} \mathrm{C} \mathrm{NMR}\left(\mathrm{CDCl}_{3}, 100 \mathrm{MHz}\right) \delta: 55.65\left(\mathrm{CH}_{3}\right), 144.44(2 \mathrm{CH})$, $123.21(\mathrm{C}), 129.12(\mathrm{CH}), 129.76(\mathrm{C}), 130.47(2 \mathrm{CH}), 131.37$ $(\mathrm{CH}), 132.44(\mathrm{CH}), 134.91(\mathrm{CH}), 137.46(\mathrm{C}), 165.18(\mathrm{C})$, 
192.04 (CO), 193.08 (CO) ppm; IR (KBr, $\left.v_{\max }, \mathrm{cm}^{-1}\right): 1640$, 1700, (C=O, s), 1420, $1620(\mathrm{C}=\mathrm{C}, \mathrm{m}), 705,730(\mathrm{CH}, \mathrm{m}) ; \mathrm{MS}$ $(70 \mathrm{Ev}, \mathrm{EI}) 319\left(\mathrm{M}^{+\cdot}\right), 193,119,104,76$.

\section{Conclusions}

In summary, we have found a facile and efficient method for the oxidation of symmetrical and unsymmetrical benzoins to corresponding benzils using with the environmentally friendly $\mathrm{H}_{2} \mathrm{O}_{2}$ as a sole oxidant and of $\mathrm{Mn}$ (II) Schiff base complex as catalyst under milder conditions. The Schiff base complex exhibited good catalytic activity in the oxidation of various benzil derivatives with hydrogen peroxide. The present procedure has many advantages such as short reaction times, mild conditions, easy operation procedures, easy removal catalyst, and high yields.

\section{Acknowledgment}

The authors gratefully acknowledge the financial support from the Research Council of the University of Kashan for supporting this work by Grant no. 159198/9.

\section{References}

[1] Z. B. Ogel, Y. Yuzugullu, S. Mete et al., "Production, properties and application to biocatalysis of a novel extracellular alkaline phenol oxidase from the thermophilic fungus Scytalidium thermophilum," Applied Microbiology and Biotechnology, vol. 71, no. 6, pp. 853-862, 2006.

[2] A. S. Demir, H. Hamamci, P. Ayhan, A. N. Duygu, A. C. Igdir, and D. Capanoglu, "Fungi mediated conversion of benzil to benzoin and hydrobenzoin," Tetrahedron Asymmetry, vol. 15, no. 16, pp. 2579-2582, 2004.

[3] D. Sachdev, M. A. Naik, A. Dubey, and B. G. Mishra, "Environmentally benign aerial oxidation of benzoin over copper containing hydrotalcite," Catalysis Communications, vol. 11, no. 8, pp. 684-688, 2010.

[4] J. S. Buck and S. S. Jcnkins, "Catalytic Reduction of alphadiketones and their derivatives," Journal of the American Chemical Society, vol. 51, no. 7, pp. 2163-2167, 1929.

[5] M. Weiss and M. Appel, "The catalytic oxidation of benzoin to benzil," Journal of the American Chemical Society, vol. 70, no. 11, pp. 3666-3667, 1948.

[6] S. A. Tymonko, B. A. Nattier, and R. S. Mohan, "Oxidation of benzoins to benzils using bismuth(III) nitrate-copper(II) acetate," Tetrahedron Letters, vol. 40, no. 43, pp. 7657-7659, 1999.

[7] A. M. Paul, A. C. Khandekar, and M. A. Shenoy, "Silica supported ferric nitrate nonahydrate: selective oxidation of benzoins under mild conditions," Synthetic Communications, vol. 33, no. 15, pp. 2581-2584, 2003.

[8] W. Y. Sun, N. Ueyama, and A. Nakamura, "Air oxidation of psubstituted benzoin to the corresponding benzyl catalyzed by $\mathrm{Fe}(\mathrm{II})$-cysteine peptide complexes," Tetrahedron, vol. 48, no. 9, pp. 1557-1566, 1992.

[9] J. Muzart, "Bimetallic oxidation catalysts: oxidations with tert butylhydroperoxide mediated by bis-(tributyltin oxide) dioxochromium (VI)," Synthetic Communications, vol. 19, no. 11, pp. 2061-2067, 1989.
[10] M. Okimoto, Y. Takahashi, Y. Nagata, G. Sasaki, and K. Numata, "Electrochemical oxidation of benzoins to benzils in the presence of a catalytic amount of KI in basic media," Synthesis, no. 5, pp. 705-707, 2005.

[11] M. R. Maurya, P. Saini, C. Haldar, and F. Avecilla, "Synthesis, characterisation and catalytic activities of manganese(III) complexes of pyridoxal-based ONNO donor tetradenatate ligands," Polyhedron, vol. 31, no. 1, pp. 710-720, 2012.

[12] S. I. M. Paris, Ü. A. Laskay, S. Liang et al., "Manganese(II) complexes of di-2-pyridinylmethylene-1,2-diimine di-Schiff base ligands: structures and reactivity," Inorganica Chimica Acta, vol. 363, no. 13, pp. 3390-3398, 2010.

[13] H. Naeimi and M. Moradian, "Alumina-supported metal(II) Schiff base complexes as heterogeneous catalysts in the highregioselective cleavage of epoxides to halohydrins by using elemental halogen," Polyhedron, vol. 27, no. 18, pp. 3639-3645, 2008.

[14] L. Canali and D. C. Sherrington, "Utilisation of homogeneous and supported chiral metal(salen) complexes in asymmetric catalysis," Chemical Society Reviews, vol. 28, pp. 85-93, 1999.

[15] M. Maneiro, M. R. Bermejo, M. I. Fernández, E. GómezFórneas, A. M. González-Noya, and A. M. Tyryshkin, "A new type of manganese-Schiff base complex, catalysts for the disproportionation of hydrogen peroxide as peroxidase mimics," New Journal of Chemistry, vol. 27, no. 4, pp. 727-733, 2003.

[16] H. Sharghi and H. Naeimi, "Schiff-base complexes of metal(II) as new catalysts in the high-regioselective conversion of epoxides to Halo alcohols by means of elemental Halogen," Bulletin of the Chemical Society of Japan, vol. 72, no. 7, pp. 1525-1531, 1999.

[17] K. Hori, H. Sugihara, Y. N. Ito, and T. Katsuki, "cis-selective aziridination of cis- or trans- $\alpha, \beta$-unsaturated amides using diaziridine," Tetrahedron Letters, vol. 40, no. 28, pp. 5207-5210, 1999.

[18] T. Fukuda and T. Katsuki, "Highly enantioselective cyclopropanation of styrene derivatives using $\mathrm{Co}$ (III)-salen complex as a catalyst," Tetrahedron, vol. 53, no. 21, pp. 7201-7208, 1997.

[19] T. Katsuki and Y. Yamashita, "Asymmetric Diels-Alder reaction using oxo(salen)manganese(V) complex as a Lewis acid catalyst," Synlett, vol. 829, 1995.

[20] G. Strukul, Ed., Catalytic Oxidations with Hydrogen Peroxide as Oxidant, Kluwer Academic, Dordrecht, The Netherlands, 1992.

[21] M. Arshadi, M. Ghiaci, A. Rahmanian, H. Ghaziaskar, and A. Gil, "Oxidation of ethylbenzene to acetophenone by a $\mathrm{Mn}$ catalyst supported on a modified nanosized $\mathrm{SiO}_{2} / \mathrm{Al}_{2} \mathrm{O}_{3}$ mixedoxide in supercritical carbon dioxide," Applied Catalysis $B$, vol. 119-120, pp. 81-90, 2012.

[22] V. Mirkhani, M. Moghadam, S. Tangestaninejad, I. Mohammadpoor-Baltork, and N. Rasouli, "A comparative study of oxidation of alkanes and alkenes by hydrogen peroxide catalyzed by $\mathrm{Cu}$ (salen) complex covalently bound to a Keggin type polyoxometalate and its neat counterpart," Catalysis Communications, vol. 9, no. 14, pp. 2411-2416, 2008.

[23] R. Bakshi and P. Mathur, "Organo-peroxyl compounds via catalytic oxidation of a hindered phenol and aniline utilizing new manganese(II) bis benzimidazole diamide based complexes," Inorganica Chimica Acta, vol. 363, no. 13, pp. 3477-3488, 2010.

[24] G. Sartori, R. Ballini, F. Bigi, G. Bosica, R. Maggi, and P. Righi, "Protection (and deprotection) of functional groups in organic synthesis by heterogeneous catalysis," Chemical Reviews, vol. 104, no. 1, pp. 199-250, 2004. 
[25] A. I. Vogel, Text Book of Practical Organic Chemistry, Longman, London, UK, 5th edition, 1989.

[26] T. Katsuki, "Mn-salen catalyst, competitor of enzymes, for asymmetric epoxidation," Journal of Molecular Catalysis A, vol. 113, no. 1-2, pp. 87-107, 1996.

[27] R. Noyori, M. Aoki, and K. Sato, "Green oxidation with aqueous hydrogen peroxide," Chemical Communications, no. 16, pp. 1977-1986, 2003.

[28] S. Balalaie, M. Golizeh, and M. S. Hashtroudi, "Clean oxidation of benzoins on zeolite A using microwave irradiation under solvent-free conditions," Green Chemistry, vol. 2, no. 6, pp. 277-278, 2000.

[29] M. Salavati-Niasari, "Nanodimensional microreactor-encapsulation of 18-membered Decaaza macrocycle copper(II) complexes," Chemistry Letters, vol. 34, no. 2, pp. 244-245, 2005.

[30] M. Salavati-Niasari, "Synthesis and characterization of host (nanodimensional pores of zeolite-Y)-guest [unsaturated 16membered octaaza-macrocycle manganese(II), cobalt(II), Nickel(II), Copper(II), and Zinc(II) Complexes] Nanocomposite Materials," Chemistry Letters, vol. 34, no. 10, pp. 1444-1445, 2005.

[31] M. Salavati-Niasari, "Nanoscale microreactor-encapsulation of 16-membered hexaaza macrocycle nickel(II) complexes: in situ one-pot template synthesis (IOPTS), characterization and catalytic activity," Microporous and Mesoporous Materials, vol. 92, no. 1-3, pp. 173-180, 2006.

[32] M. Salavati-Niasari and H. Banitaba, "Alumina-supported $\mathrm{Mn}(\mathrm{II}), \mathrm{Co}(\mathrm{II}), \mathrm{Ni}(\mathrm{II})$ and $\mathrm{Cu}(\mathrm{II})$ bis(2-hydroxyanil)acetylacetone complexes as catalysts for the oxidation of cyclohexene with tert-butylhydroperoxide," Journal of Molecular Catalysis A, vol. 201, pp. 43-54, 2003.

[33] M. Salavati-Niasari, J. Hasanalian, and H. Najafian, "Aluminasupported $\mathrm{FeCl}_{3}, \mathrm{MnCl}_{2}, \mathrm{CoCl}_{2}, \mathrm{NiCl}_{2}, \mathrm{CuCl}_{2}$, and $\mathrm{ZnCl}_{2}$ as catalysts for the benzylation of benzene by benzyl chloride," Journal of Molecular Catalysis A, vol. 209, no. 1-2, pp. 209-214, 2004.

[34] M. Salavati-Niasari and H. Najafian, "Catalytic oxidation of tetrahydrofuran in the presence of 14-membered hexaaza macrocyclic Copper (II) complexes with hydrogenperoxide," Journal of Chemical Research-Part S, no. 9, pp. 538-539, 2003.

[35] H. Golchoubian and S. E. Babaei, "Schiff-base complex using hydrogen peroxide as an oxidant," Chinese Journal of Catalysis, vol. 31, no. 6, pp. 615-618, 2010.

[36] J. Hu, K. Li, W. Li, F. Ma, and Y. Guo, "Selective oxidation of styrene to benzaldehyde catalyzed by Schiff base-modified ordered mesoporous silica materials impregnated with the transition metal-monosubstituted Keggin-type polyoxometalates," Applied Catalysis A, vol. 364, no. 1-2, pp. 211-220, 2009.

[37] T. Shamim, D. Choudhary, S. Mahajan, R. Gupta, and S. Paul, "Covalently anchored metal complexes onto silica as selective catalysts for the liquid phase oxidation of benzoins to benzils with air," Catalysis Communications, vol. 10, no. 14, pp. 1931-1935, 2009. 

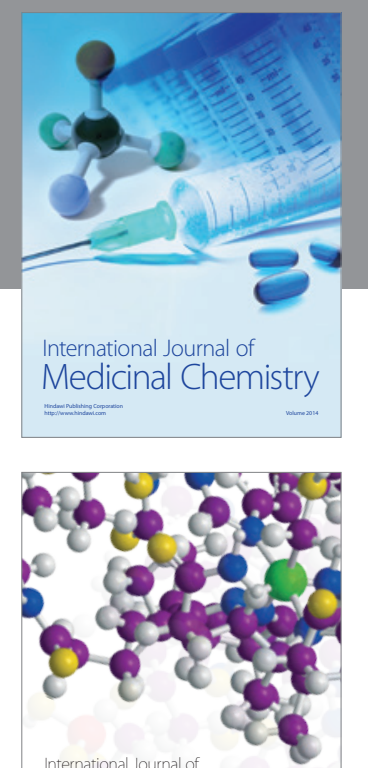

\section{Carbohydrate} Chemistry

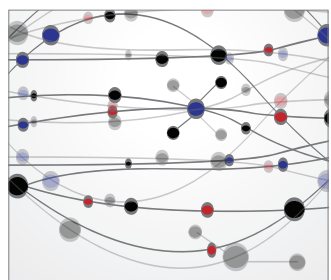

The Scientific World Journal
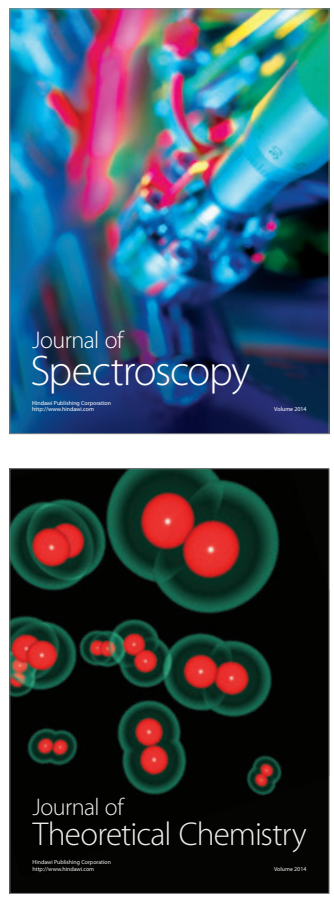
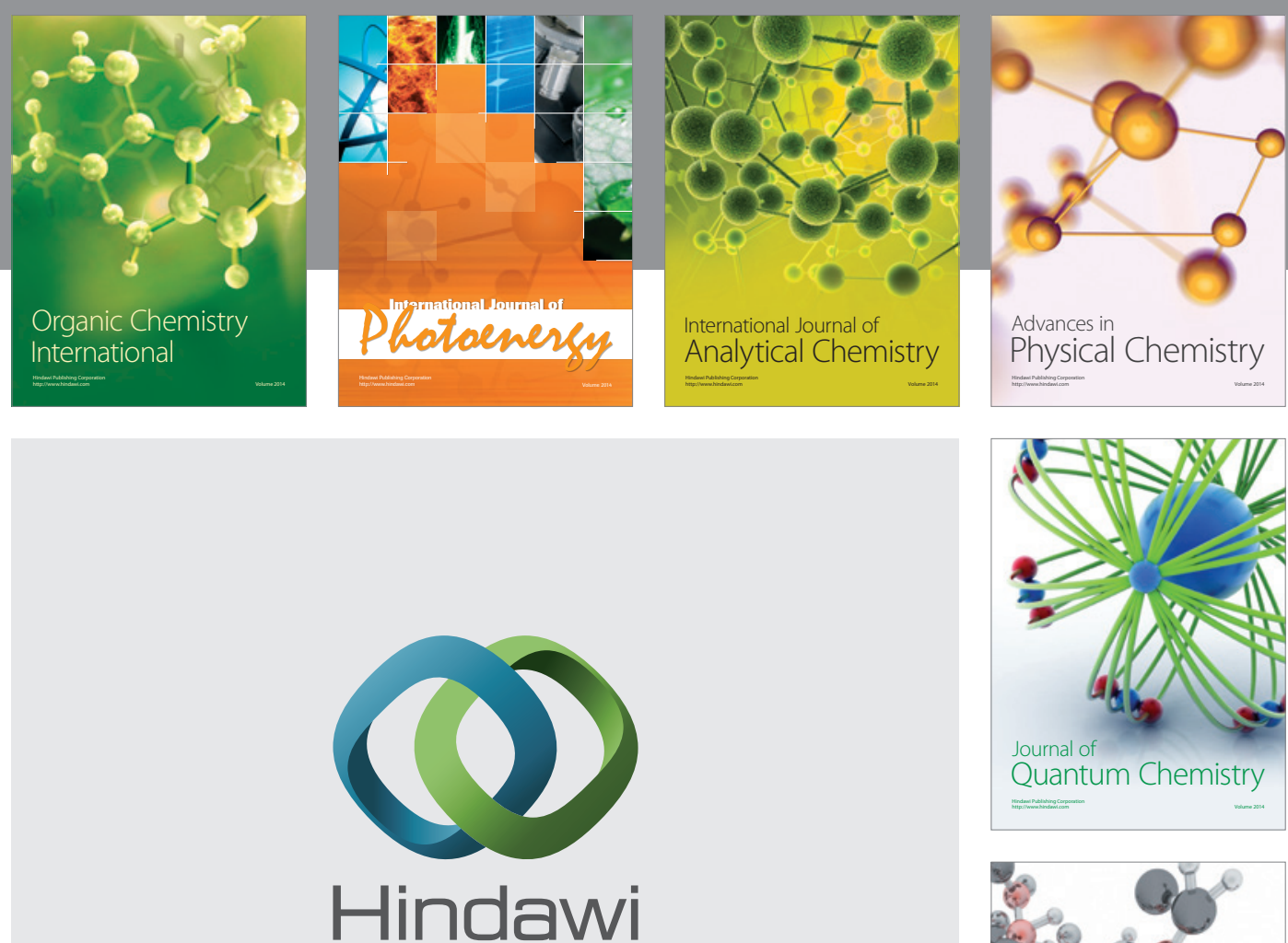

Submit your manuscripts at

http://www.hindawi.com

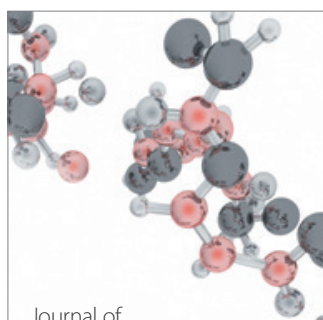

Analytical Methods

in Chemistry

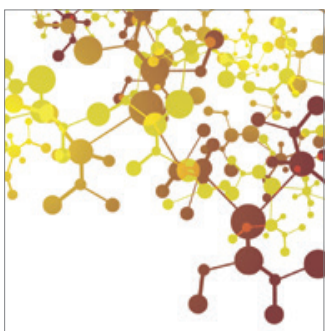

Journal of

Applied Chemistry

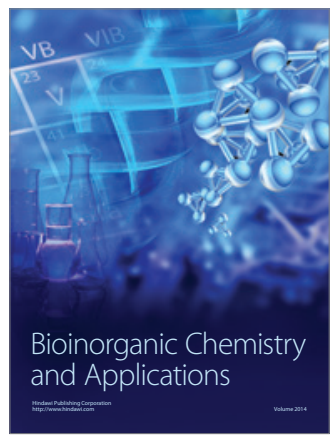

Inorganic Chemistry
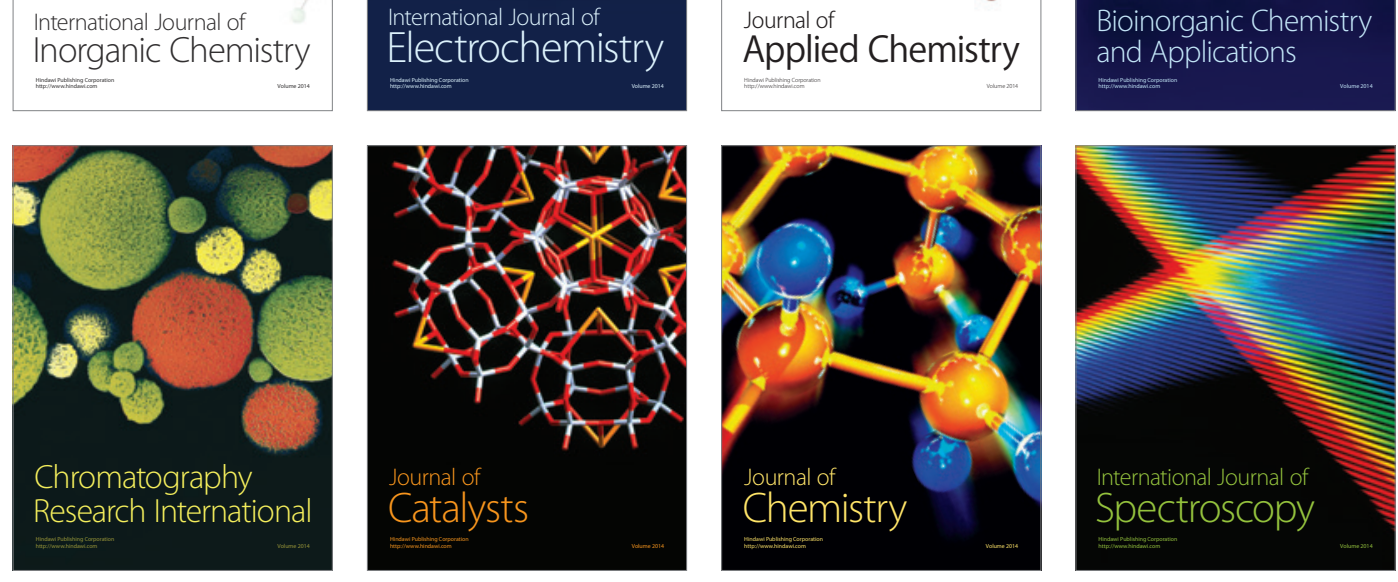